\title{
Papillary Squamous Cell Carcinoma of the Trachea Associated with Human Papillomavirus-18 Infection
}

\author{
Hisao Imai ${ }^{1}$, Toshiaki Takahashi ${ }^{1}$, Tetsuhiko Taira ${ }^{1}$, Madoka Kimura ${ }^{1}$, Yukiko Nakamura ${ }^{1}$, \\ Hirotsugu Kenmotsu ${ }^{1}$, Tateaki Naito ${ }^{1}$, Reiko Watanabe ${ }^{2}$, Haruyasu Murakami ${ }^{1}$, \\ Yasuhisa Ohde ${ }^{3}$, Masahiro Endo ${ }^{4}$, Takashi Nakajima ${ }^{2}$ and Nobuyuki Yamamoto ${ }^{1}$
}

\begin{abstract}
A 75-year-old man presented with the chief complaints of coughing and dyspnea. Chest computed tomography revealed narrowing of the trachea. A tumor measuring $40 \times 33 \times 15 \mathrm{~mm}$ in size that caused $-90 \%$ reduction in the cross-sectional area of the trachea $4 \mathrm{~cm}$ above the carina was cauterized with high-frequency electrocautery via a rigid bronchoscope. A pathological examination revealed papillary squamous cell carcinoma with immunohistochemical p16 overexpression. Multiplex polymerase chain reaction confirmed human papillomavirus type 18 DNA in the tumor. At the 12-month follow-up visit following the administration of radiotherapy, the patient exhibited no local recurrence or distant metastasis.
\end{abstract}

Key words: tracheal cancer, squamous cell carcinoma, human papillomavirus type 18, p16

(Intern Med 52: 2785-2788, 2013)

(DOI: 10.2169/internalmedicine.52.0736)

\section{Introduction}

Primary cancer of the trachea is extremely rare (1); accounting for $0.1-0.4 \%$ of all newly diagnosed airway cancers, or 2.6 new cases per 1,000,000 people per year $(2,3)$. In tracheal carcinogenesis, malignant transformation may be idiopathic or due to carcinogen exposure, immunosuppressant use, radiation or smoking $(4,5)$. Tracheobronchial papilloma is a well-known tumor caused by human papillomavirus (HPV) infection $(4,5)$ whose malignant transformation into squamous cell carcinoma is common (6). We herein report a case of papillary squamous cell carcinoma of the trachea associated with HPV-18 infection.

\section{Case Report}

A 75-year-old man presented with the chief complaints of coughing and dyspnea on exertion that had worsened over the previous three months. He consulted a physician, who identified an intratracheal lesion on chest computed to- mography (CT) and referred the patient to our hospital for further treatment. Although the patient was a former smoker, his work environment did not expose him to any known carcinogens. His cough became intractable and he developed stridor.

Chest CT (Fig. 1) showed narrowing of the trachea $4 \mathrm{~cm}$ above the carina due to an intraluminal mass (size, $40 \times 33 \times$ $15 \mathrm{~mm}$ ), causing a $\sim 90 \%$ reduction in the cross-sectional area of the trachea. Brain magnetic resonance imaging (MRI) and positron emission tomography (PET) showed no metastatic lesions. Flexible bronchoscopy revealed a cauliflower-like, warty tumor above the carina (Fig. 2A).

A tumor biopsy was performed using a rigid bronchoscope under general anesthesia; however, the tumor could not be excised easily due to its solid core. Instead, the tumor was cauterized with high-frequency electrocautery, and the residual mass remained obscure.

Several papillary tumor fragments were resected. Pathologically, the papillary tumor had a loose fibrovascular core covered by atypical squamous epithelium (Fig. 3A). Squamous papillomatous epithelium was present next to the

${ }^{1}$ Division of Thoracic Oncology, Shizuoka Cancer Center, Japan, ${ }^{2}$ Division of Diagnostic Pathology, Shizuoka Cancer Center, Japan, ${ }^{3}$ Division of Thoracic Surgery, Shizuoka Cancer Center, Japan and ${ }^{4}$ Division of Diagnostic Radiology, Shizuoka Cancer Center, Japan Received for publication April 8, 2013; Accepted for publication July 17, 2013 Correspondence to Dr. Hisao Imai, m06701014@gunma-u.ac.jp 


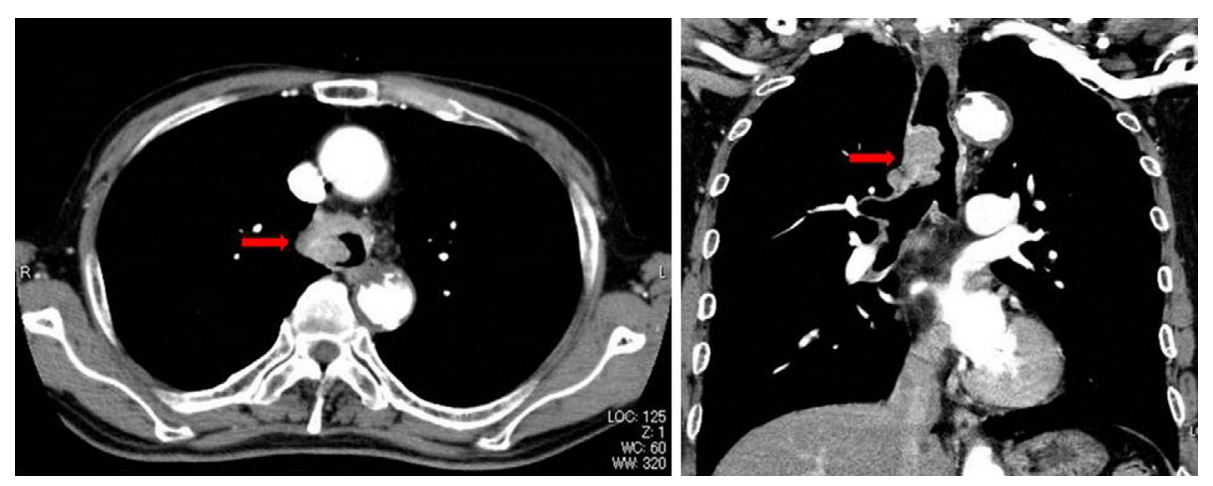

Figure 1. Chest computed tomography. Chest CT (axial view; left, coronal view; right) showing a tumor measuring $40 \times 33 \times 15 \mathrm{~mm}$ in size located $4 \mathrm{~cm}$ proximal to the carina arising from the right wall of the trachea (arrows).
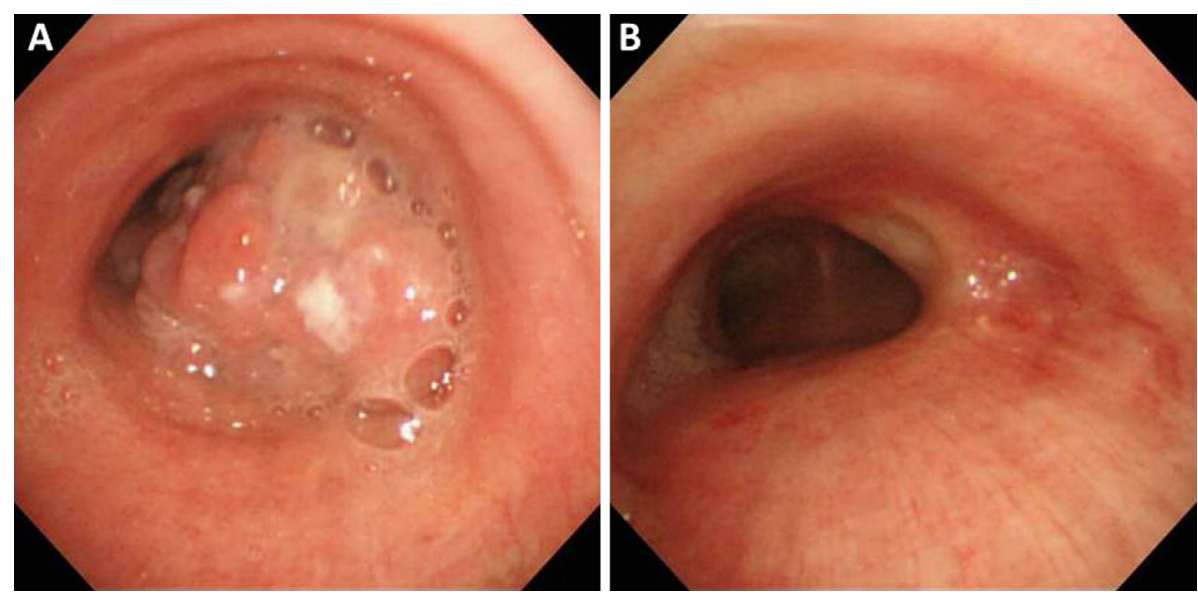

Figure 2. Endoscopic findings. A: Bronchoscopy revealed a cauliflower-like, warty tumor. B: Bronchoscopic findings after radiotherapy.

tumor tissue (Fig. 3B). The atypical squamous epithelium exhibited not only severe cellular atypia containing large nuclei with many mitoses, but also prominent bulky downward growth indicating microinvasive growth (Fig. 3A, C). Subsequently, the tumor was diagnosed as papillary squamous cell carcinoma with microinvasive growth. Immunohistochemically, the squamous cell carcinoma was diffusely and strongly positive for p16 (Fig. 3D). The tumor tissue contained small foci of immunohistochemically p16-negative squamous epithelia directly connected to the squamous cell carcinoma (Fig. 3C, D).

Tumor DNA extracted from the paraffin-embedded specimen was analyzed for the presence of HPV types $6,11,16$, $18,30,31,33,35,39,45,51,52,56,58,59$ and 66 using multiplex polymerase chain reaction [PCR (7)]. HPV type18 DNA was detected in the specimen (Fig. 4), thus suggesting that this virus had infected the tumor.

After treatment, the patient experienced immediate symptomatic relief and underwent definitive radiotherapy. The bronchoscopic findings obtained after radiotherapy revealed no residual tumor tissue (Fig. 2B). At the 12-month followup visit after resection, the patient remained recurrence-free.

\section{Discussion}

In the present case, the tumor specimen exhibited cauliflower-like or papillary growth, and the histology was different from that of ordinary squamous cell carcinoma. The results of a low-power view observation hinted towards atypical squamous cell papilloma. The accurate origin of this squamous cell carcinoma remains unclear. However, the squamous cell carcinoma could have developed as a result of the transformation of squamous cell papilloma because a few fragments of squamous epithelium were present in the tumor tissue (Fig. 3B, C).

The occurrence of squamous cell papilloma in the lower airway is rare and well known to be closely related to HPV infection. Moreover, squamous cell papillomas demonstrate a highly variable rate $(8-40 \%)$ of malignant transformation (8). The risk of transformation increases with exposure to smoking and radiation $(9,10)$ and in high-risk groups of HPV infection. HPV-16 and HPV-18 infections are related to malignant transformation in patients with squamous cell papilloma (10).

In our case, the squamous cell carcinoma was immunohis- 

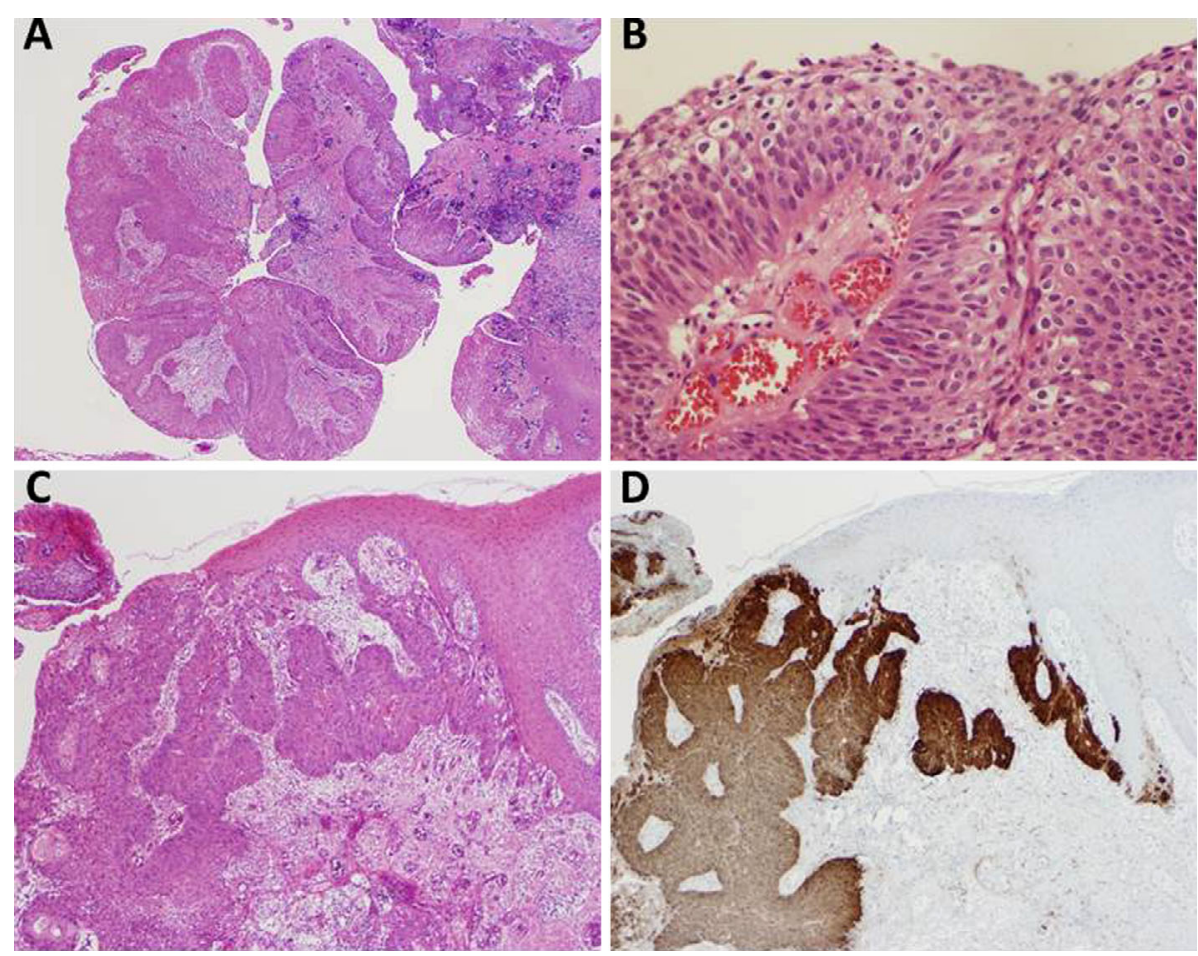

Figure 3. Histological and immunohistochemical findings. The papillary squamous cell tumor was resected via endoscopic resection (A). A few fragments of the squamous epithelium were present next to the tumor tissue $(\mathrm{B})$. The detection of severe cellular atypia with microinvasive growth $(\mathrm{A}, \mathrm{C})$ resulted in the diagnosis of papillary squamous cell carcinoma (Hematoxylin and Eosin staining, original magnification: $\mathrm{A}, \times 100 ; \mathrm{C}, \times 400$ ). In the same tumor, immunohistochemistry for $\mathrm{p} 16$ showed diffuse positivity only in the area of squamous cell carcinoma (D).

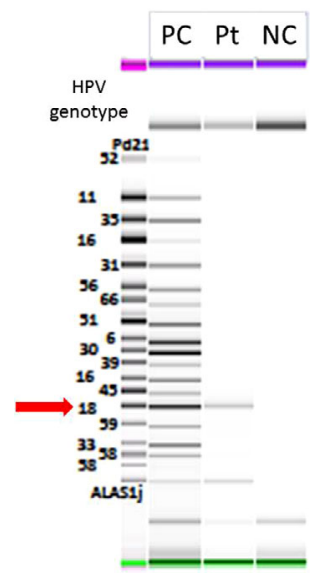

Figure 4. Results of multiplex polymerase chain reaction. The tumor was positive for human papillomavirus-18 (arrow). PC: positive control, Pt: patient, NC: negative control

tochemically positive for p16, the expression of which is used to determine the presence of biologically active HPV in patients with squamous cell carcinoma (11-13). The absence of functional phosphorylated retinoblastoma (pRB) can upregulate the p16 expression. Tobacco- and alcoholassociated head and neck squamous cell carcinomas are associated with the downregulation of p16 proteins and TP53 gene mutations, whereas HPV-associated cancers are associated with wild-type TP53 and RB1 genes and the upregula- tion of p16 proteins (14). Therefore, the p16 immunohistochemical expression indicates that the HPV-18 infection was closely related to tracheal squamous cell carcinoma in our case.

The authors state that they have no Conflict of Interest (COI).

\section{Acknowledgement}

We wish to thank Ms. Mutsumi Yamazaki, Mr. Taiki Miyauchi, Dr. Kazushige Wakuda, Dr. Takuya Oyakawa, Dr. Yasushi Hisamatsu, Dr. Akira Ono, Dr. Hiroaki Akamatsu and Dr. Takehito Shukuya for their assistance in preparing this manuscript.

\section{References}

1. Urdaneta AI, Yu JB, Wilson LD. Population based cancer registry analysis of primary tracheal carcinoma. Am J Clin Oncol 34: 3237, 2011.

2. Rostom AY, Morgan RL. Results of treating primary tumours of the trachea by irradiation. Thorax 33: 387-393, 1978.

3. Maziak DE, Todd TR, Keshavjee SH, Winton TL, Van Nostrand P, Pearson FG. Adenoid cystic carcinoma of the airway: thirty-twoyear experience. J Thorac Cardiovasc Surg 112: 1522-1531; discussion 1531-1532, 1996.

4. Rady PL, Schnadig VJ, Weiss RL, Hughes TK, Tyring SK. Malignant transformation of recurrent respiratory papillomatosis associated with integrated human papillomavirus type $11 \mathrm{DNA}$ and mutation of p53. Laryngoscope 108: 735-740, 1998.

5. Byrne JC, Tsao MS, Fraser RS, Howley PM. Human papillomavirus-11 DNA in a patient with chronic laryngotra- 
cheobronchial papillomatosis and metastatic squamous-cell carcinoma of the lung. New Engl J Med 317: 873-878, 1987.

6. Lam CW, Talbot AR, Yeh KT, Lin SC, Hsieh CE, Fang HY. Human papillomavirus and squamous cell carcinoma in a solitary tracheal papilloma. Ann Thorac Surg 77: 2201-2202, 2004.

7. Nishiwaki M, Yamamoto T, Tone S, et al. Genotyping of human papillomaviruses by a novel one-step typing method with multiplex PCR and clinical applications. J Clin Microbiol 46: 11611168, 2008.

8. Tryfon S, Dramba V, Zoglopitis F, et al. Solitary papillomas of the lower airways: epidemiological, clinical, and therapeutic data during a 22-year period and review of the literature. J Thorac Oncol: Official publication of the International Association for the Study of Lung Cancer 7: 643-648, 2012.

9. Guillou L, Sahli R, Chaubert P, Monnier P, Cuttat JF, Costa J. Squamous cell carcinoma of the lung in a nonsmoking, nonirradiated patient with juvenile laryngotracheal papillomatosis. Evidence of human papillomavirus-11 DNA in both carcinoma and papillomas. Am J Surg Pathol 15: 891-898, 1991.
10. Popper HH, el-Shabrawi Y, Wockel W, et al. Prognostic importance of human papilloma virus typing in squamous cell papilloma of the bronchus: comparison of in situ hybridization and the polymerase chain reaction. Human Pathol 25: 1191-1197, 1994.

11. Sano T, Oyama T, Kashiwabara K, Fukuda T, Nakajima T. Expression status of p16 protein is associated with human papillomavirus oncogenic potential in cervical and genital lesions. Am J Pathol 153: 1741-1748, 1998.

12. Chen ZW, Weinreb I, Kamel-Reid S, Perez-Ordonez B. Equivocal p16 immunostaining in squamous cell carcinoma of the head and neck: Staining patterns are suggestive of HPV status. Head Neck Pathol 6: 422-429, 2012.

13. Thomas J, Primeaux T. Is p16 immunohistochemistry a more costeffective method for identification of human papilloma virusassociated head and neck squamous cell carcinoma? Ann Diagnostic Pathol 16: 91-99, 2012.

14. Torrente MC, Rodrigo JP, Haigentz M Jr, et al. Human papillomavirus infections in laryngeal cancer. Head Neck 33: 581-586, 2011.

(C) 2013 The Japanese Society of Internal Medicine http://www.naika.or.jp/imonline/index.html 